\title{
Environmental fragility of Iguaçu river watershed, Paraná, Brazil
}

\author{
Fragilidad ambiental de la cuenca del río Iguaçu, Paraná - Brasil
}

\author{
Ana Paula Dalla Corte ${ }^{a *}$, Ângela Maria Klein Hentz ${ }^{\text {, }}$, Betina Doubrawa ${ }^{\text {a }}$, Carlos Roberto Sanquetta ${ }^{\text {a }}$ \\ *Corresponding author: a Federal University of Paraná, Curitiba, Brazil, anapaulacorte@gmail.com
}

\begin{abstract}
SUMMARY
The aim of this study was to analyze the environmental fragility of Iguaçu River watershed, Paraná. Regarding fragility potential, most watersheds fell under the moderate fragility class (40.47 \% of the total), followed by very low (18.83 \%), low (16.20 \%), high (13.27 \%) and very high with only $8.68 \%$. Concerning emerging fragility, most watersheds again lay within moderate fragility (41.55 \%), though in this case low fragility was found in second place (with $40.73 \%$ ), followed by very low (7.67\%), high (6.50 \%) and very high (0.99\%). Urban areas corresponded to $1.37 \%$ and bodies of water to $1.18 \%$ of the area. From a visual analysis, emerging fragility was observed to be high and very high, when present, followed by flooded areas; thus, demonstrating the importance of considering them in such studies, since they are environments with very unstable structural features including certain soil types, significant erosion from water, among others. The results of certain classes also appeared to depend on the weights given to factors considered as affecting the outcome. When the mean fragility methodology was used, the classes tended to follow a normal distribution, i.e. with a dominant moderate class. Therefore one can conclude that determining the importance of each factor is essential in evaluating environmental fragility, and therefore, weights should be carefully defined for each situation.
\end{abstract}

Key words: environmental planning, land use, vulnerability.

\section{RESUMEN}

El objetivo de este estudio fue analizar la fragilidad ambiental de la cuenca del río Iguaçu, Paraná. El potencial de la fragilidad, la mayor parte de la cuenca se encuentra en la clase media de la debilidad (40.47 \% del total), seguido por la clase muy baja (18,83 \%), baja (16,20 \%), alto (13,27 \%) y muy alta con sólo 8,68 \%. En cuanto a la fragilidad emergentes, la mayoría de la taza de nuevo está en la clase media de la debilidad (41,55 \%), pero en este caso se encontró que la baja fragilidad en el segundo lugar (con el 40,73 \%), seguido de clases muy bajas (7,67 \%), alta (6,50 \%) y muy alto (0,99\%). Las áreas urbanas corresponden a 1,37 \% y los cuerpos de agua a $1,18 \%$ de la superficie. También se observa a partir de análisis visual, las clases de fragilidad emergentes de alta y muy alta, cuando está presente, siguen las zonas de inundación, lo que demuestra la importancia de considerar en este tipo de estudios, ya que son entornos con características estructurales muy inestable debido a los tipos de suelo, la presencia de gran erosión por la fuerza del agua, entre otros. También se observó que el uso de diferentes factores de ponderación considera que afecta el resultado de ciertas clases y que cuando se utiliza la metodología de debilidad promedio de las clases es la tendencia de presentar una distribución normal, es decir, con el dominio de clase media. Por lo tanto, se puede observar que la determinación de la importancia de cada factor es dominante para la evaluación de la fragilidad ecologista, y por lo tanto, una definición de los mismos pesos evaluados para cada condición estudió.

Palabras clave: planificación ambiental, uso de la tierra, vulnerabilidad.

\section{INTRODUCTION}

The exploitation of natural resources causes different types of disturbances in the natural environment, in a variety of proportions and primarily with differing impacts, depending on the various degrees of resistance of each environment. When an environment is exploited beyond its capacity, a structural imbalance is initiated and various types of damage begin to appear, such as landslides, floods, erosion, among others. Regarding the changes in the different components of nature, Spörl and Ross (2004) state that any change in topography, soil vegetation, climate and water resources compromises the functionality of the system, breaking its state of dynamic equilibrium.

Environmental fragility is linked to the level of susceptibility to which the system is subject by certain actions, by some damaging factors or high-risk situations (Weiss 2012). This implies a failure in equilibrium and the stability of the components, causing instability and overburdening the limits of the landscape (Souza 2004). According to the Comisión Económica para América Latina y el Caribe (CEPAL 2002), vulnerability of a landscape depends on the existence of three factors: the occurrence of a negative factor, the failure to respond to a threat, either by the abs- 
ence of a human defense or the inefficiency of foreign aid, and the lack of means to adapt to high risk circumstances that arise.

Within the concept of environmental fragility, there are two important terms: potential fragility and emerging fragility. Potential fragility is defined as the natural vulnerability of an environment in terms of its physical characteristics, based on slope and soil type, while emerging fragility includes these characteristics but also considers the degree of protection for different types of land use and occupation (Kawakubo et al. 2005).

By integrating several variables interfering with the potential of natural resources, knowledge of the fragility levels in a watershed allows understanding reality and obtaining a clearer picture of the most appropriate land use options (Spörl 2001).

By mapping environmental fragility, lower fragility lands that favor certain types of development can be identified, as well as more fragile areas requiring more technically advanced interventions appropriate to those conditions (Spörl 2001). According to Tavares (2006) the rational decision-making process of environmental planning necessarily involves a reflection on the social, economic and environmental issues that guide action and any future decision.

The present study focuses on a watershed significantly occupied by human activities, and thus it is affected by a diversity of environment altering agents. The headwaters of the watershed are located in the Curitiba metropolitan area, which is a large population center and where industrial, commercial and service activities are concentrated. In contrast, agriculture and pasture are more prevalent in the interior of the state (SEMA 2013). Moreover, because of the large hydroelectric potential of Iguaçu River, several dams have been constructed along its course, which have altered the landscape.

This work brought the hypothesis that the different variable weights assigned for frailty explanatory can interfere directly in the frailty outcome (potential and emerging). This study aimed at assessing the degree of potential and emerging environmental fragility in Iguaçu River watershed in the state of Paraná, in support of land use and settlement planning and at protecting environmentally fragile land. A secondary objective tested various weights for the variables considered in order to assess the degrees of their importance, and compare them to the mean fragility.

\section{METHODS}

Iguaçu River watershed is located in the states of Paraná and Santa Catarina, and in the region of Missiones, Argentina. It is the largest watershed in the State of Paraná, occupying approximately $57,329 \mathrm{~km}^{2}$ of the state; considering the tributaries on the Santa Catarina side, it occupies a total of $69,373 \mathrm{~km}^{2}$. The length of the main channel stretches more than 1,275 km in an East-West direction (Aze- vedo 2006). The area of the watershed occupies $80.4 \%$ of the state of Paraná, $16.5 \%$ of the state of Santa Catarina, and $3 \%$ of Argentina (SEMA 2013).

Seven major aquifers are found in Rio Iguaçu watershed: the karst aquifer (Açungui Group), the fractured aquifer associated with Precambrian rocks, aquifers related to sedimentary rocks of the lower middle and upper Paleozoic, the Botucatu Formation aquifer, and the fractured aquifer of the Serra Geral Formation (Merenda 2004).

Considering plant assemblages, Iguaçu River watershed is primarily comprised of Araucaria Forest (AF) and seasonal semideciduous forest (SSF), as well as a small portion of Rain Forest (RF) and Steppes.

Iguaçu River watershed is located within a humid subtropical climatic zone with hot summers, cool winters, and no dry season. The total annual rainfall is over $1,000 \mathrm{~mm}$, with the driest month exceeding $60 \mathrm{~mm}$ (Snack 2004).

Physical variables evaluated. Variables were also defined according to the methodology of Ross (1994), who recommends an integrated analysis of the components and that each theme be assessed from a hierarchy of fragility classes, according to each theme that is developed during the analysis. The values are also assigned to each variable in each class, and are based on the work of Ross (1994) and are shown in table 1 .

All variables areas representing bodies of water or urban areas were excluded since they were considered not important in determining fragility because they are not susceptible to change. Bodies of water and urban areas were obtained from ITCG (Institute of Land and Cartography and Geosciences), derived from the slope shapefile and included with the other factors.

The slope was obtained by ITCG in vector format. Classes were calculated using the methodology of Ross (1994), but considering the existing classes, which in this case did not include all classes cited in Ross (1994).

Soil classes available in vector format from ITCG were adopted in order to categorize the degree of fragility of soil types. Weights used were those suggested by Ross (1994).

Land use was obtained from the classification of Landsat 5 TM sensor images, obtained in 2010 and with a spatial resolution of 30 meters. Segmentation was initially performed using eCognition software, separating forested from non-forested land. Subsequently, secondary successional vegetation was classified by visual interpretation using Arcgis 9.3 software.

Finally, the presence of riverbanks and flooded lands was identified. The flood limit of Iguaçu River was considered to be the first of $20 \mathrm{~m}$ contour beyond the limits of Iguaçu River. Additionally, riverbanks for the other rivers and tributaries were calculated using 30 meter buffers along the river network in Arcgis 9.3. The areas identified as flooded land and riverbanks were delineated and classified within a very high fragility index (5), while the remainder of the areas was classified within low fragility index (1). 
Table 1. Degrees of fragility by slope, soil class, vegetation cover and the presence of flooded land and riverbanks.

Grados de inclinación fragilidad, clase de los suelos, la cubierta vegetal y la presencia de llanuras de inundación y las franjas ribereñas.

\begin{tabular}{|c|c|c|c|}
\hline Theme & Value & Fragility & Slope classes \\
\hline \multirow{4}{*}{$\frac{\check{a}}{\omega}$} & 1 & Very low & $0^{\circ}$ to $10^{\circ}$ \\
\hline & 2.5 & Low/Medium & $10^{\circ}$ to $20^{\circ}$ \\
\hline & 4.5 & High/Very High & $20^{\circ}$ to $45^{\circ}$ \\
\hline & 5 & Very high & $>45^{\circ}$ \\
\hline Theme & Value & Fragility & Soil classes \\
\hline \multirow{5}{*}{ 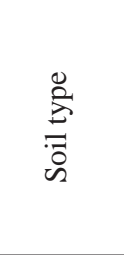 } & 1 & Very low & XanthicFerralsol, RhodicFerralsol, and HaplicFerralsol \\
\hline & 2 & Low & HaplicFerralsol (yellow and red-yellow) with medium/clayey texture \\
\hline & 3 & Mean & Clayey HaplicFerralsol (red-yellow), Alisols with medium/clayey texture \\
\hline & 4 & High & Medium/sandy texture Acrisol, Cambisol \\
\hline & 5 & Very high & Leptosol, Histosols \\
\hline Theme & Value & Protection & Types of vegetation \\
\hline \multirow{5}{*}{ 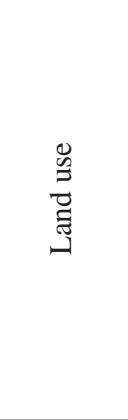 } & 1 & Very high & Forests/Natural Forests, cultivated forests with biodiversity. \\
\hline & 2 & High & $\begin{array}{l}\text { Natural Shrub Assemblages. Homogeneous dense pine forest. Cultivated } \\
\text { pastures with low cattle impact, long rotation crops. }\end{array}$ \\
\hline & 3 & Mean & Long cycle crops in contours/terracing, low cattle impact pasture, forestry. \\
\hline & 4 & Low & Low density long cycle crops, short cycle crops. \\
\hline & 5 & Very low to None & $\begin{array}{l}\text { Cleared and burned lands, exposed soil, disking, short cycle crops without } \\
\text { soil conservation measures. }\end{array}$ \\
\hline Theme & Value & Fragility & Presence/absence in riverbanks or flooded land \\
\hline 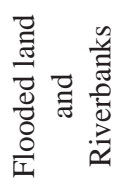 & 1 & Very high & $\begin{array}{l}\text { Other areas outside riverbanks or flooded land } \\
\text { Presence in riverbanks or in flooded Land }\end{array}$ \\
\hline
\end{tabular}

The importance of considering these riverbanks and flooded lands lies on their high fragility index, which is due to characteristics such as increased presence of redoximorphic soils and/or sediments with high intensity gleying processes. These processes occur in a reduction environment, resulting from frequent floods; exacerbated by the presence of horizons and/ or layers of low permeability, and the presence of groundwater depths less than $1 \mathrm{~m}$ for much of the year (Barddal 2006).

Different variable weights. In order to verify the existence of differences in the results using different weights for the variables analyzed, methods using different weights were sought out in literature. Many authors have tested or surveyed experts to define how important the variables in their studies are, in order to evaluate how significantly they will affect the environmental fragility in each case.

Many studies of weights were discovered, some of which are described here. One should note that the exact weights of these authors were not considered, since in most cases more variables than those appearing in the present case were included. Rather, what was evaluated was the importance of each variable with respect to the others. Table 2 presents the weighted values of all variables of this study, both for potential and for emerging fragility.

Weighting 1 was based on the factors used by Santos (2010), of which the author considered geology to be the most important, followed by slope, land use and finally the distance to springs and water resources. Thus, geology and soil type can be correlated, since they are highly dependent factors. Further that author did not distinguish between potential and emerging fragility.

The second weighting was based on the work of Martin and Roberts (2012), in which factors of topography, soil, and rock type were considered most important for potential fragility. Of these, topography, although correlated with slope, was used in the present study. For emerging fragility, potential fragility and land use the same degree of importance was assigned (50 each). 
Table 2. Weighting values for the variables.

Valores de las variables de ponderación.

\begin{tabular}{ccccc}
\hline Fragility & Factor & Weighting 1 (\%) & Weighting 2 (\%) & Weighting 3 (\%) \\
\hline Potential & Soil & 65 & 45 & 50 \\
& Slope & 35 & 55 & 50 \\
Emerging & Soil & 40 & 25 & 20 \\
& Slope & 25 & 25 & 20 \\
& Land use & 15 & 50 & 50 \\
& Riverbanks and Flooded land flood & 20 & - & 10 \\
\hline
\end{tabular}

The third level weights were based on the work of Donha et al. (2005) and Calijuri et al. (2007). These two studies used very similar factors for the same variables, with soil and slope factors having been assigned equal importance for potential fragility, and both calculated factor importance by fuzzy logic. As for emerging fragility, they considered land use to be much more important (about $50 \%$ of the total), while slope and soil type were given equal importance, and the distance to water resources was the least important.

The results of the fragilities using these factors were compared with the mean environmental fragility, the primary objective of this study, and based on the methodology of Ross (1994). Figure 1 presents a summary of the methodological approach for the weights tested in this study.

Analyses of environmental fragilities: potential and emerging. Based on the results of the weights, each of the environmental fragility factors was evaluated. The analyses were based on the work of Ross (1994) who developed the empirical analysis methodology for environmental fragility. In turn his work was based on that of Tricart (1997). The variables used for the analysis of each of the fragilities are summarized in figure 2 .

To determine the potential fragility of Iguaçu River watershed, we used equation 1 , according to the methodology of Maganhotto et al. (2011).

$$
\mathrm{PF}=(\mathrm{SC} * \mathrm{SWF})+(\mathrm{SLC} * \mathrm{STWF})
$$

Where,

$\mathrm{PF}=$ potential fragility;

$\mathrm{SC}=$ slope class;

$\mathrm{SWF}=$ slope weighting factor;

$\mathrm{SLC}=$ soil class;

STWF = soil type weighting factor.

Emerging fragility was generated from combining potential fragility with forest cover and flooded forest maps, with their respective class values. As with the determination of potential fragility, determination of mean fragility was prioritized for emerging fragility, obtained from equation 2 and adapted from Maganhotto et al. (2011).

$\mathrm{PE}=(\mathrm{SC} * \mathrm{SWF})+(\mathrm{SLC} * \mathrm{STWF})+(\mathrm{LU} * \mathrm{LUWF})+(\mathrm{RBF} * \mathrm{RBFWF})[2]$

Where,

$\mathrm{PE}=$ Emerging fragility;

$\mathrm{SC}=$ slope class;

$\mathrm{SWF}=$ slope weighting factor;

$\mathrm{SLC}=$ soil class;

STWF = soil type weighting factor;

$\mathrm{LU}=$ Land Use;

LUWF = land use weighting factor;

$\mathrm{RBF}=$ riverbanks and flooded land;

RBFWF $=$ riverbanks and flooded land weighting factor.

Thus existing thematic maps were combined, resulting in fragility values and the weights tested. The results of these formulas differ between whole and fractional numbers but levels identified suggested the corresponding intervals in figure 2 .

\section{RESULTS}

The maps resulting of the potential and emerging fragility of Iguaçu River watershed according to the methodology of Ross (1994) are shown in figures 3 and 4, respectively. Complementarily, the areas of potential fragility are quantified, as shown in table 3.

Analyses of potential fragility information revealed that most of the landscape, or $40.47 \%$ of the total, is distributed within the moderate potential fragility class. The very low fragility class occupies $18.83 \%$, while the low fragility class corresponds to $16.20 \%$ of the landscape. Likewise, $13.27 \%$ corresponds to high fragility class and $8.68 \%$ to the very high fragility class. Bodies of water comprised $1.18 \%$ and urban areas comprised $1.37 \%$.

Therefore a good portion of the watershed can be considered in stable condition, $75.5 \%$ in very low, low and medium fragility, while only $21.95 \%$ of areas are of high or very high fragility. 


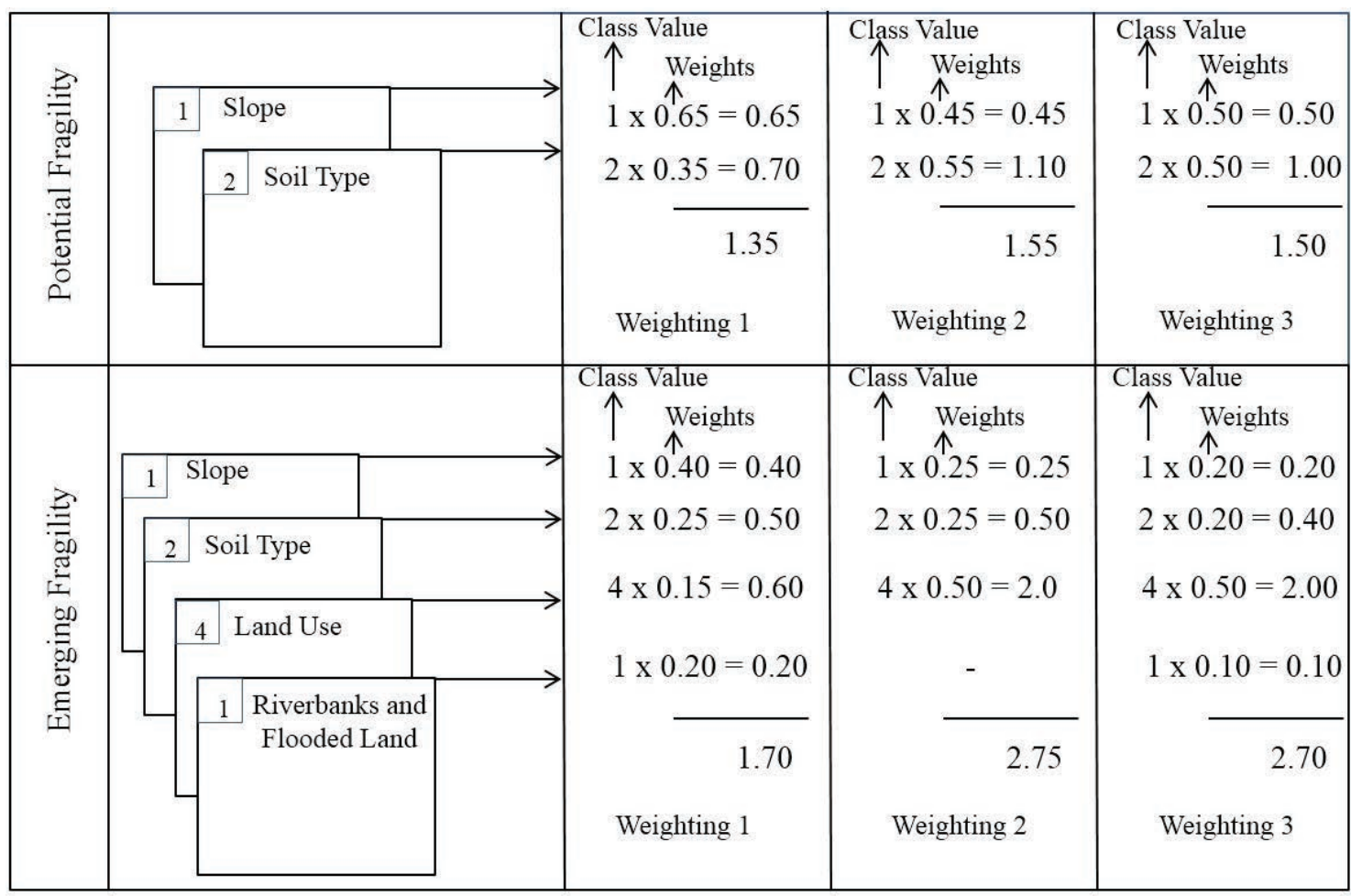

Figure 1. Summary of weights for the tested variables adopted in this study.

Resumen de pesos aprobados para las variables analizadas en este trabajo.

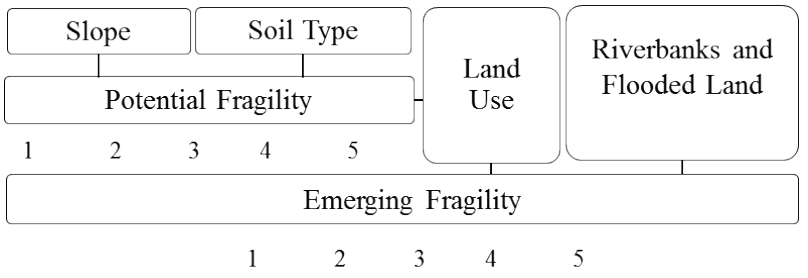

Figure 2. Variables used for assessing environmental fragility. Where: 1-very low $(<1.5)$; 2-low $(1.5<2.5)$; 3-medium $(2.5<$ 3.5); 4-high $(3.5<4.5)$; 5-very high $(\geq 4.5)$.

Variables adoptadas en la evaluación de la fragilidad del medio ambiente. Donde: 1 -muy bajo $(<1.5)$; 2-bajo $(1.5<2.5)$; 3 -medio $(2.5$ $<3.5)$; 4-alto $(3.5<4.5)$; 5 -muy alto $(\geq 4.5)$.

Visually one can observe that the very high potential fragility class is highly concentrated in the central region of the watershed, while the very low class is generally distributed in the western portion of the study area. The other classes do not demonstrate strong trends.

Emerging fragility resulted from the correlation of potential environmental fragility classes with land use classes and the presence of flooded lands, as seen in figure 4. In the same way that the potential environmental fragility class was quantified, emerging fragility classes were also quantified as shown in table 4.
Table 3. Quantification of areas according to potential environmental fragility classes.

Cuantificación de áreas según clases de fragilidad ambiental potencial.

\begin{tabular}{lrc}
\hline \multicolumn{1}{c}{ Potential fragility } & Area (ha) & \multicolumn{1}{c}{$\%$} \\
\hline 1 - Very low & $1,026,174$ & 18.83 \\
2 - Low & 882,867 & 16.20 \\
3 - Medium & $2,205,301$ & 40.47 \\
4 - High & 723,310 & 13.27 \\
5 - Very high & 472,886 & 8.68 \\
Watercourses & 64,196 & 1.18 \\
Urban area & 74,701 & 1.37 \\
\hline Total & $5,449,435$ & 100.00 \\
\hline
\end{tabular}

In analyzing table 4, one can see that most of the area corresponds to the moderate fragility class, occupying $41.55 \%$ of the total area of Iguaçu River watershed. The low emerging fragility class was the second largest with $40.73 \%$. The next largest was very low fragility with 7.67 $\%$, and the high fragility with $6.50 \%$ of the study area, and finally very high emerging fragility with only $0.99 \%$. Figure 4 shows the spatial distribution of the emerging classes of fragility in the watershed. 


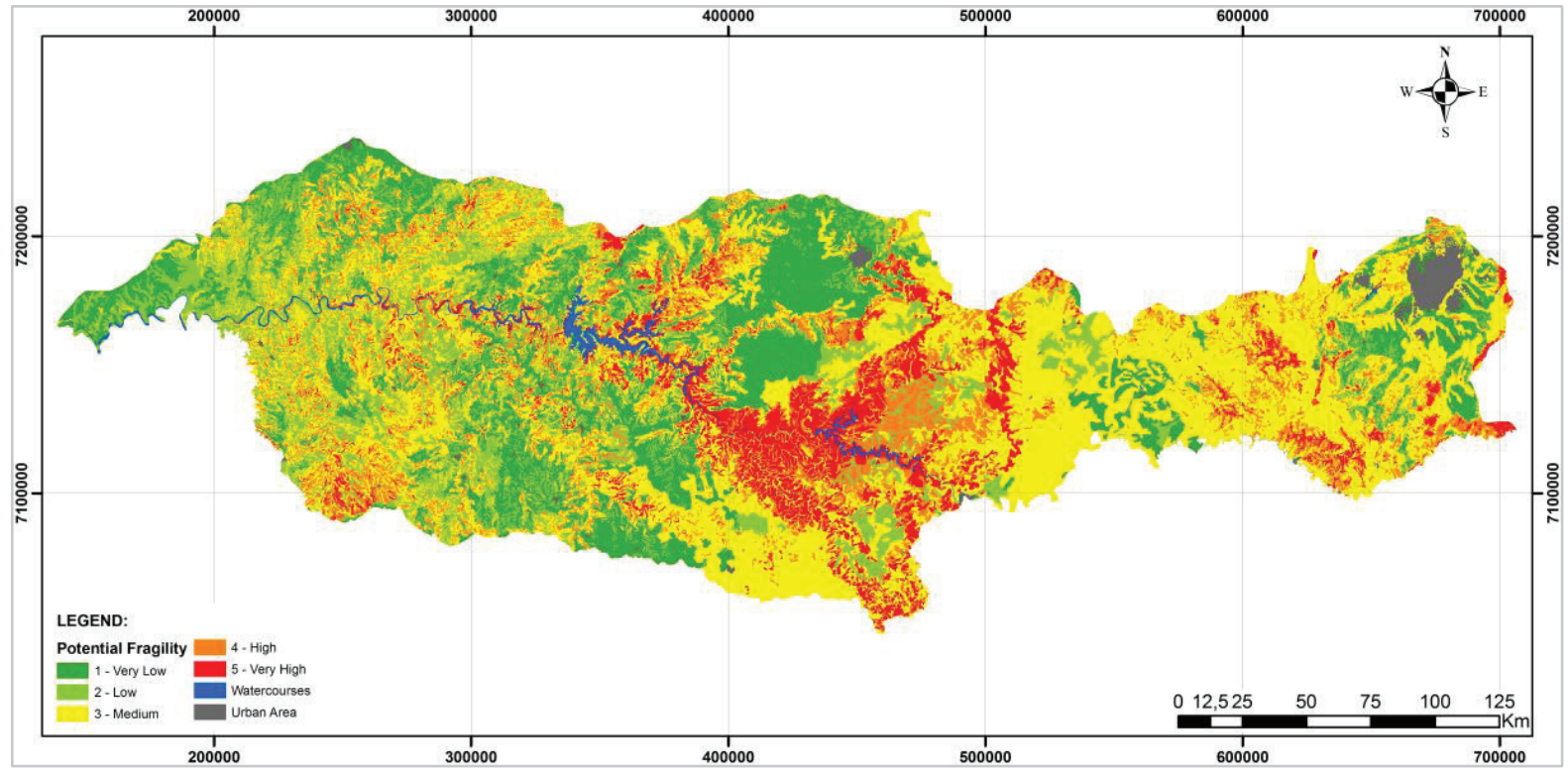

Figure 3. Potential fragility of Iguaçu River watershed, Paraná, Brazil.

Potencial de fragilidad ambiental de la cuenca del río Iguaçu, Paraná, Brasil.

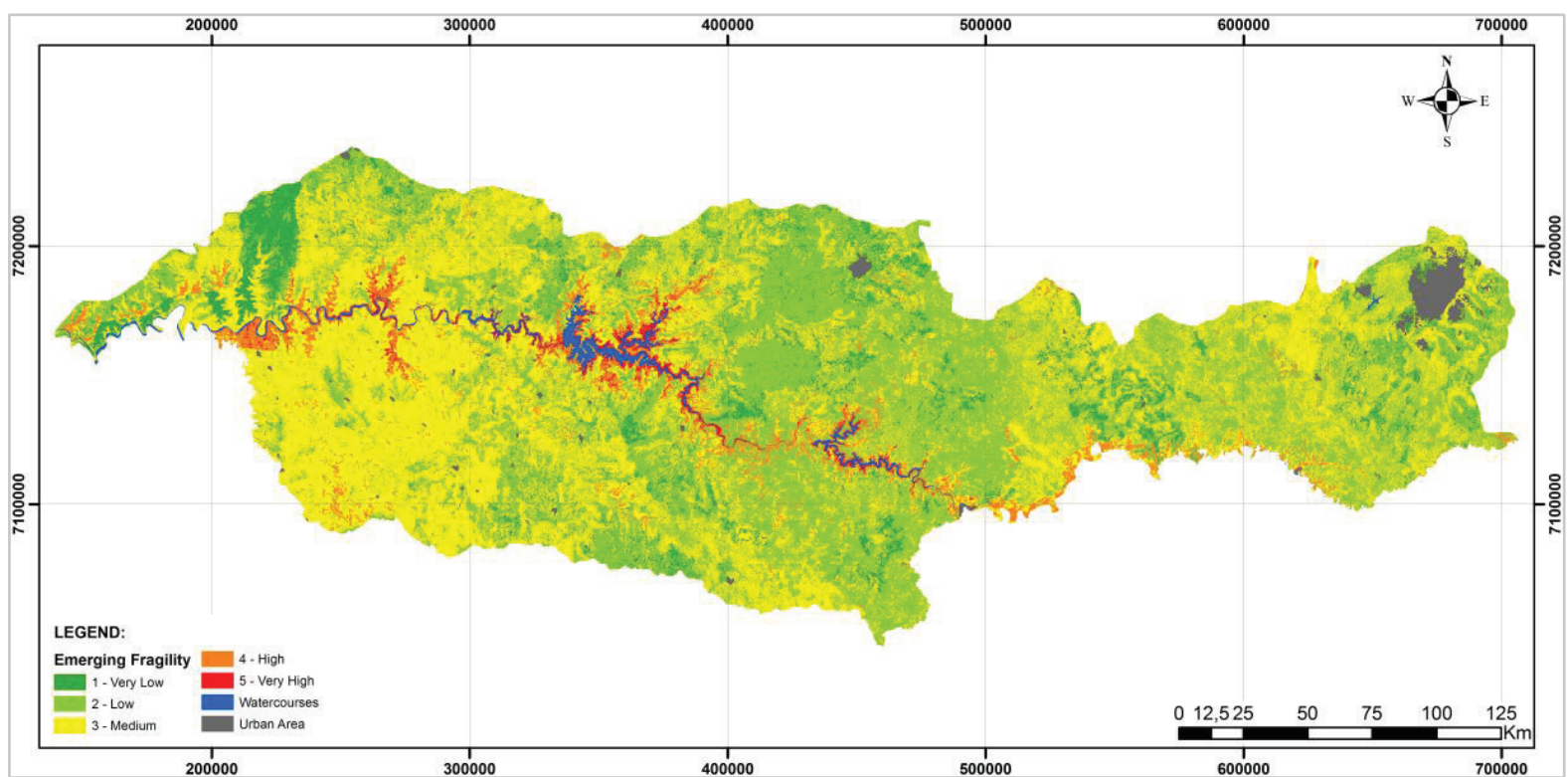

Figure 4. Emerging environmental fragility of Iguaçu River watershed, Paraná, Brazil.

Fragilidad ambiental emergente de la cuenca del río Iguaçu, Paraná, Brasil.

Thus, almost all areas were found to be in a relatively good emerging fragile state, because the sum of very low, low and medium fragility represented $89.95 \%$ of the entire area of the watershed, and only $7.49 \%$ were high or very high emerging fragility areas. The remaining areas were bodies of water and urban areas.

In comparing tables 3 and 4 , it can be deduced that much of the potential fragility that was very low, became low in emerging fragility. There was virtually no difference between mean potential fragility and mean emerging fragility. Also high and very high classes of emerging fragility were reduced compared to potential fragility.

In figure 4 one can visually analyze the very high emerging fragility class is located mostly on flooded lands. Ross (1994) believes the condition as highly limiting to land use. 
Table 4. Quantification of areas according to emerging environmental fragility classes.

Cuantificación de áreas según clases de fragilidad ambiental emergente.

\begin{tabular}{lrr}
\hline \multicolumn{1}{c}{ Emerging fragility } & Area (ha) & \multicolumn{1}{c}{$\%$} \\
\hline 1 - Very low & 418,168 & 7.67 \\
2 - Low & $2,219,691$ & 40.73 \\
3 - Medium & $2,264,407$ & 41.55 \\
4 - High & 354,245 & 6.50 \\
5 - Very high & 54,026 & 0.99 \\
Bodies of water & 64,196 & 1.18 \\
Urban area & 74,701 & 1.37 \\
\hline Total & $5,449,435$ & 100.00 \\
\hline
\end{tabular}

Variable weights. As detailed in the methodology, we tested different combinations of weights among the variables tested, including soil type, slope, land use and the presence of flooded land or riverbanks. The weights were determined from values found in other studies. Although the same weights were not used, the importance of the variables was used.

Three different weightings were used, each with different weights for the variables. The results of the determination of fragility classes for each case and the mean weight are shown in table 5.

The very low fragility class for the potential fragility appeared to remain unchanged, in spite of the fact that weightings 1 and 2 differed and the two factors also differed. In weighting 1 soil was considered of higher importance and received superior weight while in weighting 2 the opposite was the case. Weight 3 took into account soil and slope with the same degree of importance, and hence found the same values in the calculation of mean potential fragility.

The importance of the choice of the most significant factors is most visible in emerging fragility. In analyzing Table 5, one can also see that the percent occupation and all classes were very influenced by the choice of weights. In verifying table 5 and figure 5 , it is clear that the very low class remained the most constant, followed by the very high class.

\section{DISCUSSION}

As shown before, in results, most of the landscape is distributed within the moderate potential fragility class, followed by the fragility class low and very low. In a study by Maganhotto (2011) in the Irati National Forest, of a total 3,495 ha the highest area percentage was attributed to the low potential fragility class (53\%), while moderate fragility class occupied $26 \%$ of the study area. The results are very similar to those found in the present study.

Although few areas have been classified as of high fragility in this study, this watershed deserves special attention of the national authorities because it presents one of the greatest energy and water supply potentials of the country. Iguaçu is the longest river in Paraná state, with a length of 1,320 km (SEMA 2013), and it is essential to the socioeconomic development of the region. In addition, this watershed plays an important ecological role as shelter to flora and fauna of the endangered Atlantic Rain Forest. Furthermore, various environmental protection sites, such as Iguaçu National Park (a UNESCO world heritage) and federal protection reserves (Rio Verde, Passaúna, Iraí, Rio Pequeno, and Guaratuba) (SEMA 2010), are located along Iguaçu basin.

Another study by Messias et al. (2012) of the Funil dam in the sub-watershed of Rio Grande in Minas Gerais,

Table 5. Comparison of the use of different weights for percentage occupancy of potential and emerging environmental fragility classes. Comparación del uso de diferentes pesos para los porcentajes de clases de fragilidad ambiental potencial y emergente.

\begin{tabular}{|c|c|c|c|c|c|c|c|c|}
\hline \multirow{2}{*}{ Fragility classes } & \multicolumn{4}{|c|}{ Weights for potential fragility } & \multicolumn{4}{|c|}{ Weights for emerging fragility } \\
\hline & 1 & 2 & 3 & Mean & 1 & 2 & 3 & Mean \\
\hline 1 - Very low & 18.83 & 18.83 & 18.83 & 18.83 & 5.89 & 5.57 & 7.69 & 7.67 \\
\hline 2 - Low & 17.89 & 28.77 & 16.20 & 16.20 & 35.50 & 22.20 & 23.31 & 40.73 \\
\hline 3 - Medium & 20.49 & 27.90 & 40.47 & 40.47 & 42.63 & 28.75 & 32.06 & 41.55 \\
\hline 4 - High & 31.91 & 13.27 & 13.27 & 13.27 & 12.90 & 36.90 & 30.99 & 6.50 \\
\hline 5 - Very high & 8.33 & 8.68 & 8.68 & 8.68 & 0.53 & 4.04 & 3.41 & 0.99 \\
\hline Watercourse & 1.18 & 1.18 & 1.18 & 1.18 & 1.18 & 1.18 & 1.18 & 1.18 \\
\hline Urban area & 1.37 & 1.37 & 1.37 & 1.37 & 1.37 & 1.37 & 1.37 & 1.37 \\
\hline Total & 100 & 100 & 100 & 100 & 100 & 100 & 100 & 100 \\
\hline
\end{tabular}

Where: The values reflect the $\%$ occupancy of each class with respect to the total area. 

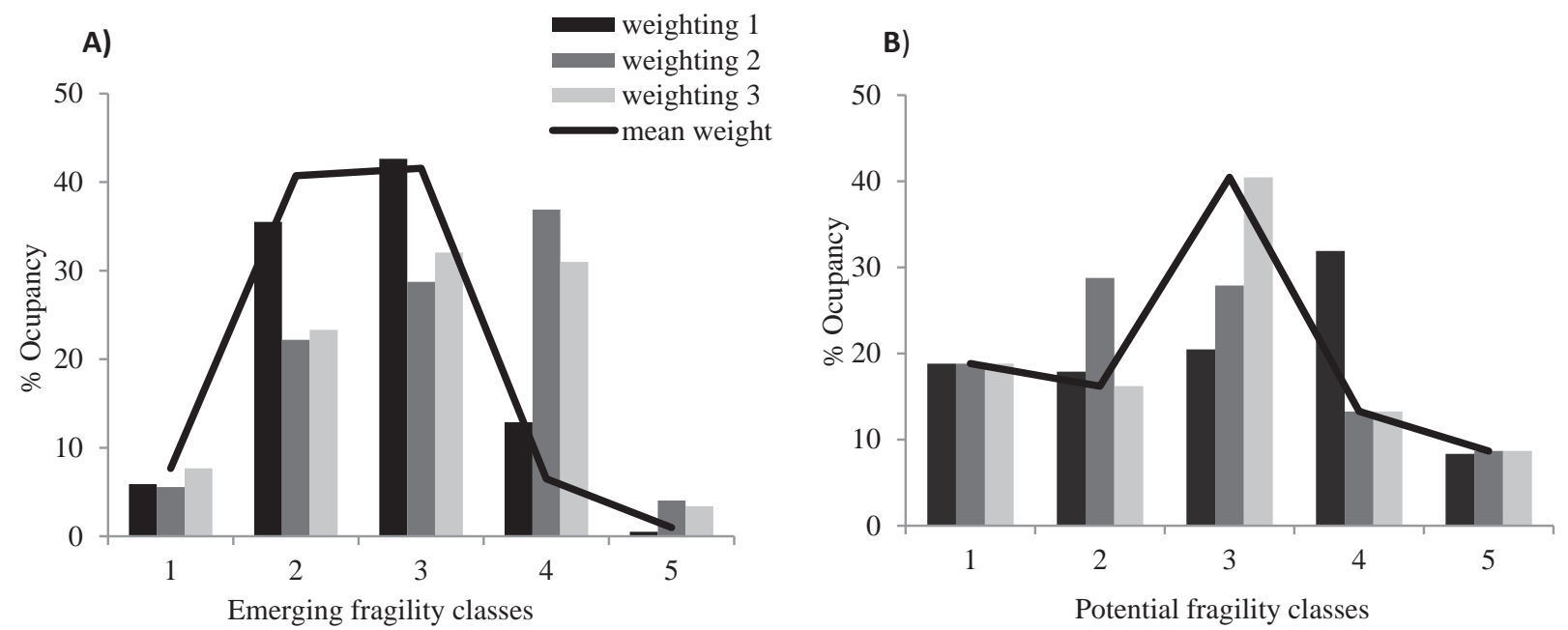

Figure 5. Comparison of results obtained for each class of potential environmental fragility (A) and emerging fragility (B) for different variable weights. de las variables.

Comparación de los resultados obtenidos para cada clase de potencial fragilidad ambiental (A) y emergen (B) las distintas ponderaciones

reported a predominance of the moderate potential fragility class, followed by the high fragility class. Some sites had low potential fragility due to low soil vulnerability and weak topography desiccation. But they also found a very high potential fragility class, the most vulnerable to erosive processes.

In the study of Rio das Pedras in Guarapuava, Paraná by Pachechenik (2005), the highest percentage of potential fragility was found in the moderate class occupying $41.67 \%$ of the study area. The percentage of 33.27 of the Rio das Pedras watershed made this area be classified as of potentially high environmental fragility, and $4.76 \%$ of the area was found as of potentially very high environmental fragility. This differs from the present study in which the largest percentage was found in the lower and moderate class of potential fragility.

It is also worth to note that even those areas where there is moderate potential weakness may present high levels of emerging weakness, usually due to poor land use associated with human presence, that in this basin is around 3.9 million inhabitants (SEMA 2013). This is why the conservation practices need to be met in spite of the inherent characteristics of the environment, such as soil type, topography, among others.

About emerging fragility, there is a higher occupancy of the middle class, lower class and finally very low, as can be seen in table 4. Messias (2011) also found a predominance of the mean emerging fragility. Human activities are possible on land with moderate desiccation of the topography associated with moderate vulnerability, provided that they are accompanied by specialized professionals and that permanent preservation areas are respected.

When the potential and emerging fragility figures are compared, it is observed that unlike the previously assu- med, the degree of fragility did not tend to increase. Still, it is observed that the regions with higher degrees of potential fragility showed low levels of emerging fragility, which can be answered by small population found in this portion, corresponding to the medium part of Iguaçu watershed. This central region is characterized by an economy not so much devoted to agriculture when compared to the western part of the basin, but with high presence of forest plantations (IPARDES 2013), which were modified by human action but in a lower intensity, which helps to protect the soil due to ground coverings to prevent mainly the runoff from rain (Enders et al. 2006).

In the study of Rio das Pedras watershed in Guarapuava, Paraná by Pachechenik (2005), $48.66 \%$ of the total watershed area was observed in the emerging low environmental fragility class. Land use in these areas consists of native forest and reforestation. Only $1.60 \%$ of the total area of the watershed lies in the very high emerging environmental fragility class.

The very high emerging fragility class is located mostly on flooded lands. Because of their steep slopes these places are susceptible to erosive processes, since they are subject to flooding along the banks and to accumulation generated by fluvial dynamics (Messias 2011). It is essential that these sites have vegetation cover, since the soil type is highly vulnerable. In addition, these areas appear as a very specific vegetation type, called alluvial forests, which have, in the case of the area of Araucaria Forest, distinct characteristics of size and predominant species groups, as Sebastiania commersoniana for instance (Scheer and Blum 2011).

One can also observe that the very low and low emerging fragility classes in Iguaçu National Park were large expanses of preserved forests in moderate to advanced secondary successional stages. 
The very low fragility class for the potential fragility appeared to remain unchanged with different weights used. This same result for the very low weightings class informs us that the class is too low stipulated by the two factors considered, soil and slope, i.e., they also agree that this class is very low, hence the weighting does not affect the result. This same pattern was observed for the very high potential fragility class.

In other classes of potential fragility, weightings heavily influenced results. With weighting 1 , the class with the highest occurrence was high fragility, while for the weighting class 2 the highest occurrence was low fragility; for weighting 3 and for the mean weighting, the moderate class had the highest occurrence. The biggest difference, however, was found in the high fragility class, where weighting 1 yielded $31.9 \%$, and in all others yielded $13 \%$. This allows us to infer that soil may be the most important in identifying this as a high fragility class, since it was apparent only when soil type was considered. Thus, there are likely many soil types with high potential fragility, which are found on less fragile (less steep) slopes.

Regarding the use of different factors, one can observe that each weighting generates a different result, but in some classes less so than in others. This is due to the fact that some factors are in agreement in some classes and differ in others. In this case, the factor with the most important weight will predominate.

The very low class remained the most constant, even using different weights, followed by the very high class. This is because all factors likely agree that the classes are either too low or too high with respect to emerging fragility.

Weighting 3 was the only one which did not consider the presence of flooded land and riverbanks, but the difference between this and other classes was not as high as expected. Furthermore in this weighting the largest areas were seen in the very low emerging fragility class, and also in the very high fragility class, which can reveal that they are important factors in differentiating between extreme fragility levels.

In addition, in the weighting that gave the highest weight to the presence of floodplains and riparian strips (weighting 2 with $20 \%$ significance) the lowest percentage of occupancy ( $0.53 \%$ ) was obtained in the very high fragility class, indicating that while the other variables placed some areas in the very high fragility class, they were not flooded land or riverbanks, and hence were not acknowledged as fragile when this factor was considered. Likewise for the mean fragility, where flooded land and riverbanks were given the same weight as other variables (1/3 each), the very high fragility class was very small (0.99\%).

Figure 5 strikingly shows that the classes most influenced by the weights were the central (low, medium and high). The very high class proved to be greatly influenced in emerging fragility, in which the presence of flooded lands was considered (in weighting 1 and mean weighting).
This class rarely occurred, though was more abundant within the flooded lands (in weightings 2 and 3).

Calijuri et al. (2007) also compared different types of weights. They compared his results, in the weightings were derived from fuzzy logic, with the results of the methodology of Crepani et al. (2001), who also used mean fragility, i.e., all factors have the same importance. He found that when the mean fragility was used, the distribution of classes was normal or near normal, as also observed in the present study.

About Calijuri et al. (2007), the authors also comment that in the work of Crepani et al. (2001), there was little difference between potential and emerging fragility, and thus the land use factor did significantly contribute. In this case however, a large difference between potential and emerging fragility was observed, in some classes more than others, but since the presence of flooded land and riverbanks was considered, the significance of land use could not be determined. Thus, Calijuri et al. (2007) found that using equal weights can mask results and, as Spörl cites, according to which the methodology that assigns the same weight to different variables of the analysis may "mask" or attenuate fragility results (Spörl 2001).

Another interesting study in this line of research is Spörl (2001), who considered the differences among three different methodologies to calculate the environmental fragility, namely: topography desiccation index, slope classes (Ross 1994) and basic territorial units (Crepani et al. 2001). The author makes a series of observations about the differences among the methods, and comments that the procedures used by Crepani et al. (2001), in which the arithmetic mean of the values (parameters) for each variable is applied and results in the attenuation of the outcome, tend to yield values all positioned at median intervals.

However he also found that the models of Ross (1994), who considers slope/relief classes to be more important, can cause exaggeration, as it can result in fragility that is too pronounced for a very desiccated area, when actually other variables reduce their vulnerability, or may determine a fragility that is too low for a level topography, while other variables accentuate the vulnerability (Spörl 2001).

In another study, Pedrosa et al. (2012) compared various weights of variables in determining the fragility of sheet erosion. This study again came to the same conclusion about the models that assign the same importance to all factors: that they tend to concentrate in the moderate class.

Finally, all authors agree that the use of different weights alter results, and are thus important, according to Pedrosa et al. (2012) "weights must be assigned very carefully, and results should be verified taking into account the spatial variability of the attributes evaluated." Spörl (2001) goes on to comment that determining the best model (between classes and weighted means) is not possible first comparing these models with empirical realities on field. 


\section{CONCLUSIONS}

The results of the analyses using different themes suggests that in the study area, there is a higher proportion of the moderate class of potential fragility, followed in order by very low, low, high and very high classes. In the case of emerging fragility, again the most frequent class was moderate fragility, followed by the low, very low, high and very high classes, in order of land area occupied by the class. For emerging fragility, the very high class essentially tracks the flooded land.

Though high and very high fragility areas show smaller proportional in terms of the total area of the watershed, both for potential and emerging, it is remarkable that the basin needs to be protected, because it has an outstanding economic and environmental importance. These areas are among those presenting the most important water availability in the state and still are well protected by well-preserved forest cover.

One can also conclude that the methodology of environmental fragility analysis is highly dependent on the choice of weighting factors adopted in each analysis. Their determination from specific tests and analyses, whenever field observations are available, is recommended.

\section{REFERENCES}

Azevedo LC. 2006. Análise da Precipitação Pluvial da Bacia do Rio Iguaçu - Paraná. Master Thesis in Geografia. Maringá, Brasil. Departamento de Geografia, Universidade Federal de Maringá. 109 p.

Barddal ML. 2006. A influência da saturação hídrica na distribuição de 8 espécies arbóreas da Floresta Ombrófila Mista aluvial do rio Iguaçu, PR, BR. PhD Thesis in Engenharia Florestal. Curitiba, Brasil. Universidade Federal do Paraná. $116 \mathrm{p}$.

Calijuri ML, JEM Alves, AC Baptista, AF Santiago, SSP Loures. 2007. Proposta metodológica para geração da carta de fragilidade ambiental, utilizando lógica fuzzy e combinação linear ponderada. In Proceedings of XIII Simpósio Brasileiro de Sensoriamento Remoto. Florianópolis, Brasil. p. 3311-3318.

CEPAL (Comisión Económica para América Latina y el Caribe, CL). 2002. Socio-demographic vulnerability: old and new risks for communities, households and individuals. Consulted 13 de set. 2011. Available in http://www.cepal.org/ publicaciones/xml/2/9662/SES29-16-I.pdf.

Crepani E, JS Medeiros, LG Azevedo, V Duarte, P Hernandez, T Florenzano, C Barbosa. 2000. Sensoriamento Remoto e Geoprocessamento Aplicados ao Zoneamento Ecológico- Econômico e ao Ordenamento Territorial. São José dos Campos, Brasil. INPE. 124 p.

Donha AG, LCP Souza, ML Sugamosto. 2006. Determinação da fragilidade ambiental utilizando técnicas de suporte à decisão e SIG. Revista Brasileira de Engenharia Agrícola e Ambiental 10(1): 175-181.

Endres PA, TCT Pissarra, MJ Borjes, W Politano. 2006. Quantificação das classes de erosão por tipo de uso do solo no município de Franca - SP. Engenharia Agrícola 26(1): 200-207.
IPARDES (Instituto Paranaense de Desenvolvimento Econômico e Social, BR). 2013. Indicadores de desenvolvimento sustentável por bacias hidrográficas do Estado do Paraná. Consulted 22 abr. 2015. Available in http://www.meioambiente. pr.gov.br/arquivos/File/indicadores.pdf.

Kawakubo FS, RG Morato, KC Campos, A Luchiari, JLS Ross. 2005. Caracterização empírica da fragilidade ambiental utilizando geoprocessamento. In Proceedings of XII Simpósio Brasileiro de Sensoriamento Remoto. Goiânia, Brasil. p. 2203-2210.

Maganhotto RF, LJC Santos, PCF Oliveira. 2011. Análise da fragilidade ambiental como suporte ao planejamento do ecoturismo em unidades de conservação: estudo de caso Flona de Irati-PR. Revista Floresta 41(2): 231-242.

Martins TIS, SC Rodriques. 2012. The use of geotechnologies in the landscape fragility analysis of medium lower Araguari river basin, Brazil. Investigaciones Geográficas 44: 3-16.

Merenda EA. 2004. Reservatório de Segredo e área de entorno: aspectos legais e modificações no uso do solo. Master Thesis in Geografia. Maringá, Brasil. Departamento de Geografia, Universidade Federal de Maringá. 70 p.

Messias CG. 2011. Análise da fragilidade ambiental na área de influência da Hidrelétrica do Funil-MG, utilizando-se de imagens do satélite ALOS sensor PRISM. Undergraduate Thesis in Geografia. Alfenas, Brasil. Instituto de Ciências da Natureza, Universidade Federal de Alfenas. 71 p.

Messias CG, MFM Ferreira, MBP Ribeiro, MD Menezes. 2012. Análise empírica de fragilidade ambiental utilizando técnicas de geoprocessamento: o caso da área de influência da hidrelétrica do Funil - MG. Revista Geonorte 2(4): 112-125.

Pachechenik PE, JLM Souza. 2005. Estudo do processo chuvavazão na bacia do rio das Pedras, Guarapuava, Estado do Paraná, com o modelo HYCYMODEL. Acta Scientiarum Agronomy 27(4): 677-686.

Pedrosa AS, EAV Rocha, SC Rodrigues. 2012. Proposta de Modelagem da Suscetibilidade à Erosão Laminar. Um Estudo de Caso na Bacia do Ribeirão Vai-Vem (GO), Brasil. Revista Geonorte 2(4): 1707-1720.

Ross JLS. 1994. Análise Empírica da Fragilidade dos Ambientes Naturais e Antropizados. Revista do Departamento de Geografia 8: 64-74.

Santos AA. 2010. Geoprocessamento Aplicado à Identificação de Áreas de Fragilidade Ambiental no Parque Estadual da Serra do Rola Moça. Specialization Thesis in Geoprocessamento. Belo Horizonte, Brasil. Departamento de Cartografia, Universidade Federal de Minas Gerais. 39 p.

Scheer MB, CT Blum. 2011. Arboreal Diversity of the Atlantic Forest of Southern Brazil: From the Beach Ridges to the Paraná River. In Grillo O, G Venora eds. The Dynamical Processes of Biodiversity - Case Studies of Evolution and Spatial Distribution. Rijeka, Croatia. Intech. p. 109-134.

SEMA (Secretaria de Estado do Meio Ambiente e Recursos Hídricos, BR). 2013. Bacia do Rio Iguaçu. Consulted 18 jul. 2013. Available in http://www.aguasparana.pr.gov.br/arquivos/File/BACIAS/iguacu.pdf.

SEMA (Secretaria de Estado do Meio Ambiente e Recursos Hídricos, BR). 2010. Bacias Hidrográficas do Paraná, uma Série Histórica. Consulted 22 abr. 2015. Available in http:// www.meioambiente.pr.gov.br/modules/conteudo/conteudo. php?conteudo=176.

Souza GBN. 2004. Degradação ambiental e a ocupação do 
solo na várzea do Rio Ouricuri, Capanema (PA). Revista GeoUerj (edição especial): 800-807.

Sporl C. 2001. Análise da fragilidade Ambiental Relevo Solo com Aplicação de Três Modelos Alternativos nas Altas Bacias do Rio laguari-Mirim, Ribeirão do Quartel e Ribeirão da Prata. Master Thesis in Geografia Física. São Paulo, Brasil. Faculdade de Filosofia, Letras e Ciências Humanas, Universidade de São Paulo. 159 p.

Sporl C, JLS Ross. 2004. Análise comparativa da fragilidade ambiental com aplicação de três modelos. GEOUSP - Espaço e Teтpo 15: 39-49.
Tavares JA. 2006. Fragilidade Ambiental da Bacia Hidrográfica do Rio Punaú (RN) e Área Adjacente Litorânea. Master Thesis in Geografia. Natal, Brasil. Departamento de Geografia, Universidade Federal do Rio Grande do Norte, $178 \mathrm{f}$.

Tricart J. 1977. Ecodinâmica. Rio de Janeiro, Brasil. IBGE/SUPREN. $91 \mathrm{p}$.

Weiss R. 2012. Identificação de fragilidade ambiental quanto a enchentes e desmoronamentos no perímetro urbano de Santa Maria - RS por geotecnologias. Master Thesis in Geomática. Santa Maria, Brasil. Centro de Ciências Rurais. Universidade Federal de Santa Maria. 108 p.

Recibido: 22.08 .14

Aceptado: 04.05.15 
